\section{Cooper Union for the Advancement of Science and Art}

THE eighty-third annual report of the Cooper Union for the Advancement of Science and Art, New York, covers the year ending June 30, 1942, and includes the report of the director, Mr. E. S. Burdell, with the departmental reports of the School of Engineering, the Art School, the Library, the Division of Social Philosophy, and the Division of Business Administration. Dealing with the effect of America's entry into the War upon American education, Mr. Burdell hints that the United States Office of Education may assign a specific training task to each college in terms of its capacity, equipment and personnel. He further predicts the year-round operation of many colleges and particularly of engineering schools. The post-war demand for scientifically trained personnel for rehabilitation and reconstruction purposes promises to be as great as the existing demand for trained men for the armed services. Teaching staffs, however, must not be called upon to face a twelve-month academic year with rest periods on a catch-as-catch-can basis. Colleges which anticipate year-round operation should be prepared to adopt the 'quarter-off' system which already works successfully in the State universities now on a foursemester basis, where a member of the teaching staff may expect his non-teaching semester during any nne of the four quarters, which usually correspond to the four seasons of the year.

A third great challenge which American colleges must face during or shortly after the War is in the field of co-operative education. Stressing the way in which the co-operative scheme of alternating school work and shop practice strengthens vocational orientation, and the union of theory and practice, Mr. Burdell points out that the present tendency is for longer periods of alternation between college and the industries and that the most important functionary in the operation of the co-operative system is the co-ordinator. The value of the system has been well demonstrated in the experience of the University of Cincinnati, the pioneer in this movement, and for engineers the system teaches the student to do his best naturally and as a matter of course, as well as affording an appreciation of the human factor in practical affairs. In the second part of his report, Mr. Burdell refers to the question of student health and suggests a comprehensive study of the effects of stress, continuous and prolonged, upon the physical and mental stamina of young adults, which the Cooper Union has under consideration.

\section{Evolution of International Trade}

IN an address before the Manchester Statistical Society on March 10, on some essential factors in the evolution of international trade, Prof. A. G. B. Fisher stressed the importance, if we wish to maintain or improve our standard of living, of being prepared constantly to adjust our export activities to meet the probable changes in circumstances arising through changes in the character of employment, and of being constantly on the alert to initiate changes on our own account which are likely to be advantageous to us. British export trade flourished during the nineteenth century because we were able to supply people in other countries with things which they were eager to purchase, and he urged a careful study of the figures for total and expanding exports with reference to other exports. We should consider how best we could prepare to make further adjustments after the War which would be suitable in the different conditions of world demand which will then exist. What is more, we should ensure that those adjustments would be made on a scale sufficiently large to assure us that balance of payments equilibrium at which we must aim. He stated that material progress will be impossible unless there is free admission into the occupations and industries where increased production is necessary to provide consumers with the things without which no increase in their real incomes will be forthcoming. Scientific and technical knowledge have always been the most important factors underlying economic progress, so the basis for the adiustments of the structure of world trade which will in any event be necessary is already available for us to build on. Such considerations are already receiving serious attention in other parts of the world, particularly in Switzerland, where Swiss industry is preparing to meet the new demands which peace will bring to it. Many industrial concerns there are strengthening their technical staff and increasing the number of their scientific collaborators, making resources available for research and constructing laboratories.

\section{Ventilation of Electrical Substations}

THE type of construction used for substations is generally governed by requirements, for example, fire and air-raid precautions, which may conflict with the maintenance of the atmospheric conditions necessary for keeping the equipment in good order. These conditions are not necessarily the same as those needed for human comfort, and the application of heat alone has often been found to be ineffective and costly. In a paper read in London before the Institution of Electrical Engineers, F. Favell and E. W. Connon record their experiences in overcoming substation ventilation problems in particular cases. Adequate and suitably planned ventilation will maintain substation equipment in a satisfactory condition with a far smaller use of heat than has generally been considered necessary. Further collaboration by manufacturers, for example, in designing gear which would be unharmed by the occasional condensation that might occur in an unheated building, might enable heating to be dispensed with entirely. It is not certain that present-day switchgear will be affected adversely by occasional bad conditions, and further investigation of this matter is required. Substation equipment and the buildings housing it should be designed and constructed as a complete unit. The paper discusses the subject under the headings of typical arrangement of a large indoor substation, conditions required in substations, the effects of unsuitable conditions, arrangements of ventilating plant, transformers inside buildings, and application to smaller substations.

\section{Australian Antarctic Expedition}

THE first volume of the "Scientific Reports (Series A) of the Australasian Antarctic Expedition of 1911-14" has now been published (Sydney, Government Printing Office, 1942. £3 17s. 6d). The long delay was due to many causes, of which the most important was the usual difficulty that scientific expeditions have to face, namely, lack of funds. This large volume contains 350 pages of text, more than a hundred illustrations and nine maps. The text is 